\title{
New insights into the cell cycle profile of Paracoccidioides brasiliensis
}

\author{
A.J. Almeida ${ }^{\text {a }}$, M. Martins ${ }^{\text {a }}$, J.A. Carmona ${ }^{\text {a }}$, L.E. Cano ${ }^{\text {b }}$, A. Restrepo ${ }^{\text {b }}$, \\ C. Leão ${ }^{a}$, F. Rodrigues ${ }^{\mathrm{a}, *}$ \\ ${ }^{a}$ Life and Health Sciences Research Institute (ICVS), School of Health Sciences, University of Minho, Braga, Portugal \\ ${ }^{\mathrm{b}}$ Medical and Experimental Mycology Group, Corporación para Investigaciones Biológicas (CIB), Medellín, Colombia \\ Received 10 November 2005; accepted 12 January 2006 \\ Available online 24 April 2006
}

\begin{abstract}
The present work focuses on the analysis of cell cycle progression of Paracoccidioides brasiliensis yeast cells under different environmental conditions. We optimized a flow cytometric technique for cell cycle profile analysis based on high resolution measurements of nuclear DNA. Exponentially growing cells in poor-defined or rich-complex nutritional environments showed an increased percentage of daughter cells in accordance with the fungus' multiple budding and high growth rate. During the stationary growth-phase cell cycle progression in rich-complex medium was characterized by an accumulation of cells with higher DNA content or pseudohyphae-like structures, whereas in poor-defined medium arrested cells mainly displayed two DNA contents. Furthermore, the fungicide benomyl induced an arrest of the cell cycle with accumulation of cells presenting high and varying DNA contents, consistent with this fungus' unique pattern of cellular division. Altogether, our findings seem to indicate that $P$. brasiliensis may possess alternative control mechanisms during cell growth to manage multiple budding and its multinucleate nature.
\end{abstract}

(C) 2006 Elsevier Inc. All rights reserved.

Keywords: Paracoccidioides brasiliensis; Flow cytometry; Multiple budding; Cell cycle profile; Cell cycle arrest

\section{Introduction}

The dimorphic pathogenic fungus Paracoccidioides brasiliensis, the etiologic agent of paracoccidioidomycosis (PCM), undergoes a complex transformation in vivo and also in vitro at $36-37^{\circ} \mathrm{C}$, consisting in the switch from a mycelial non-pathogenic form that grows at environmental temperatures to a yeast pathogenic form occurring at the temperature of the mammalian host (Queiroz-Telles, 1994). PCM is one of the most prevalent invasive fungal infections in Latin America essentially affecting immunocompetent individuals. As in other fungi, thermodimorphism is an important virulence trait of $P$. brasiliensis representing a crucial step in its pathogenicity (San Blas et al., 2002). However, the bases underlying the cellular and molecular processes involved in the morphological transition of this

\footnotetext{
${ }^{*}$ Corresponding author. Fax: +351 253604809.

E-mail address: frodrigues@ecsaude.uminho.pt (F. Rodrigues).
}

human pathogen are still unknown (Restrepo-Moreno, 2003).

P. brasiliensis yeast cells are generally characterized by the pilot's wheel appearance, i.e., a multiple budding mother cell surrounded peripherally by daughter cells, though short chains of blastoconidia or cells with single buds may also be observed (Queiroz-Telles, 1994; Restrepo-Moreno, 2003). Both mycelia and yeast cells feature multiple nuclei, whereas conidia-supposedly the natural infectious propagules - present only a single nucleus (San Blas, 1986). Even though knowledge concerning several aspects of the biology of $P$. brasiliensis has increased, little attention has been given so far to issues such as the regulation of the cell cycle and the interaction between DNA replication, nuclei segregation and budding. The control mechanisms that underlie cell growth and nuclear/cellular division of the eukaryote model system Saccharomyces cerevisiae have been extensively studied. During normal growth conditions, this single budding yeast progresses to a specific "start" point in the $G_{1}$ phase 
of the cell cycle which precedes the triggering of three cell cycle milestones, namely initiation of budding, initiation of DNA synthesis and spindle-body duplication as a primary step of nuclear division (Hartwell, 1974; Hartwell et al., 1974). Interestingly, cell cycle control mechanisms different than those of $S$. cerevisiae have been described in other microorganisms, such as bacteria from the archaeal genus Sulfolobus or the opportunistic fungus Cryptococcus neoformans (Bernander, 1998; Hjort and Bernander, 2001; Ohkusu et al., 2001; Takeo et al., 2004). These organisms seem to possess alternative checkpoints for the regulation of cell cycle progression, specifically in what concerns DNA synthesis and cell division.

The main goal of this work was to analyze the cell cycle profile of $P$. brasiliensis yeast cells under different environmental conditions. We have evaluated cell cycle progression along different phases of growth in batch cultures, namely in defined and complex media. Furthermore, the effect of benomyl on such profile was also analyzed. Methyl benzimidazole-2-yl-carbamate, the active component of this drug, has been shown to disturb microtubule assembly in $S$. cerevisiae, inducing mitotic chromosome loss (Rodrigues et al., 2003) and cause metaphase arrest with blocking of the cells in the $\mathrm{G}_{2} / \mathrm{M}$ phases of the cell cycle (Wood, 1982a,b). In order to achieve the proposed objectives, we optimized a flow cytometry (FCM) technique for the evaluation of the cell cycle profile of $P$. brasiliensis yeast cells based on nuclear DNA content, using SYBR Green I, a probe with high affinity for double stranded DNA (dsDNA) (Fortuna et al., 2000).

\section{Materials and methods}

\subsection{Strains and media}

Paracoccidioides brasiliensis yeast cells, strain ATCC 60855 , a Colombian isolate, were maintained at $36^{\circ} \mathrm{C}$ by periodic subculturing in slanted tubes with brain heart infusion (BHI) solid media (1.5\% wt/vol agar) supplemented with $1 \%$ glucose. For the assays carried out in this study, yeast cells were routinely grown in both $\mathrm{BHI}$ and modified synthetic McVeigh Morton (MMcM) (Restrepo and Jimenez, 1980) liquid medium, at $36^{\circ} \mathrm{C}$ with aeration on a mechanical shaker $(200 \mathrm{rpm})$.

\subsection{Microscopic count methods and cell viability assays}

Direct microscopic counts of yeast cell suspensions were carried out using bright-field microscopy and Neubauer counting chamber procedures (cells were considered individually for count methods). Cell viability (colony-forming ability) was measured by plating serial dilutions of yeast cultures onto BHI plates supplemented with $1 \%$ glucose and colony counting after 15 days of incubation at $36^{\circ} \mathrm{C}$.

\subsection{Cell cycle analysis}

P. brasiliensis yeast cells were cultured in BHI liquid medium supplemented with $1 \%$ glucose to an early stage of the exponential phase of growth. When indicated, cells were harvested, washed with distilled sterile water, and suspended in $\mathrm{MMcM}$ medium. Samples were collected at defined culture times by centrifugation ( $4000 \mathrm{~g}$ for $5 \mathrm{~min}$ at $4^{\circ} \mathrm{C}$ ). An overnight fixation was carried out with $70 \%$ ethanol (vol/ vol) at $4{ }^{\circ} \mathrm{C}$, a procedure that does not perturb the formation of dsDNA/SYBR Green I complexes. After fixation, cells were harvested, washed and suspended at $1 \times 10^{7}$ cells $/ \mathrm{ml}$ in $1 \mathrm{ml}$ of sodium citrate buffer $(50 \mathrm{mM}$; $\mathrm{pH} 7.5)$, an optimal staining condition for this fluorochrome (Fortuna et al., 2000). The suspensions were then subjected to three consecutive ultrasound (Sonics Vibra-cell; Newton, CT, USA) pulses at $40 \mathrm{~W}$ for $1 \mathrm{~s}$, with an interval of $1-2 \mathrm{~s}$ between each pulse. After sonication, cell suspensions were treated for 30 , 60 , and $75 \mathrm{~min}$ at $50^{\circ} \mathrm{C}$ with RNase $\mathrm{A}(0.25,0.5$, and $0.75 \mathrm{mg} /$ $\mathrm{ml})$ and/or with proteinase $\mathrm{K}(0.5,1,1.5$, and $2 \mathrm{mg} / \mathrm{ml})$. To facilitate formal validation of the optimization process, a cell concentration of $1 \times 10^{7} \mathrm{cells} / \mathrm{ml}$ was stained overnight at $4^{\circ} \mathrm{C}$ with SYBR Green I (Molecular Probes, Eugene, OR, USA) at a final concentration of $25 \times$ throughout all assays. For titration procedures, cell staining was carried out with SYBR Green I at final concentrations ranging from $0.01 \times$ to $100 \times$. Before FCM analysis, Triton ${ }^{\circledR}$ X-100 (SigmaAldrich, St. Louis, MO, USA) was added to samples at a final concentration of $0.25 \%(\mathrm{vol} / \mathrm{vol})$.

\subsection{Flow cytometry measurements}

All FCM experiments were performed on an EPICS XLMCL (Beckman-Coulter, Hialeah, FL, USA) flow cytometer equipped with an argon-ion laser emitting a $488 \mathrm{~nm}$ beam at $15 \mathrm{~mW}$. The green fluorescence was collected through a $488 \mathrm{~nm}$ blocking filter, a $550 \mathrm{~nm} /$ long-pass dichroic with a $525 \mathrm{~nm} /$ band-pass and a $590 \mathrm{~nm} /$ long-pass with a $620 \mathrm{~nm} /$ band-pass, respectively. A minimum of 30,000 cells per sample was acquired at low flow rate and an acquisition protocol was defined to measure forward scatter (FS) and side scatter (SS) on a four-decade logarithmic scale and green fluorescence (FL1) on a linear scale. Offline data were analyzed with the Multigraph software included in the system II acquisition software for the EPICS XL/XLMCL version 1.0 and statistical analysis was carried out with the Windows Multiple Document Interface for Flow Cytometry 2.8 (WinMDI 2.8).

Cell sorting was performed on a $\mathrm{MoFlo}^{\circledR}$ high speed cell sorter (DakoCytomation; Fort Collins, CO, USA) configured with two lasers for 488 and $633 \mathrm{~nm}$ excitation simultaneously. For fluorescence-activated cell-sorter purification, P. brasiliensis yeast cell samples, strain ATCC 60855, were prepared as described above for cell cycle analysis. Both FS LOG and FL1 measurements were carried out in order to define subpopulations for cell sorting. The purity of cell preparations was $>80 \%$. 


\subsection{Epifluorescence microscopy analysis}

Epifluorescence microscopy was performed on a Zeiss Axioskop epifluorescence microscope fitted with $10 \times$ eyepieces and $40 \times$ and $100 \times$ (oil immersion) objectives and equipped with a Carl Zeiss AxioCam (HR/MR). Due to lower sensitivity of this technique comparatively to FCM, SYBR Green I cell staining was carried out with a final concentration of $80 \times$.

\subsection{Benomyl treatment}

P. brasiliensis yeast cells were cultured in MMcM liquid medium to a stationary phase of growth. Cells were then harvested, washed with distilled sterile water and suspended in $\mathrm{MMcM}$ liquid medium in order to obtain a final cell number of about $3 \times 10^{6}$ cells $/ \mathrm{ml}$. Benomyl solutions were prepared in dimethyl sulfoxide (DMSO) in such a manner that the final concentration of this organic solvent in the culture medium never exceeded $1 \%$ ( $\mathrm{vol} / \mathrm{vol})$, a concentration that on our preliminary analysis revealed no effect on cell growth or viability. Treatments with different concentrations of the antifungal agent were performed at $36^{\circ} \mathrm{C}$ with aeration on a mechanical shaker $(200 \mathrm{rpm})$. Samples for cell cycle analysis, cell viability assays and direct microscopic counts were collected at the times indicated in Section 3.

\subsection{Reproducibility of the results and statistical analysis}

All experiments were repeated at least three times with duplicate samples. The data regarding FCM protocol optimization are from one representative experiment, while data from cell cycle profile analysis are reported as mean values (standard deviation $\leqslant 10 \%$ ). Statistical analysis regarding treatment of $P$. brasiliensis yeast cells with benomyl was carried out by Two-way ANOVA using the GraphPad Prism
Software version 4.00. Percentage of individual cell subpopulations were compared between treated and untreated conditions at all intervals indicted in Section 3.

\section{Results}

The present study focused on the characteristics of the cell cycle profile of Paracoccidioides brasiliensis yeast cells during batch culturing and under the effects of benomyl, an antifungal drug known to promote a cell cycle arrest in the G2/M phases of Saccharomyces cerevisiae (Wood, 1982a,b). Taking into consideration the proposed objectives and specific traits of this pathogenic fungus, we optimized a previously described protocol for $S$. cerevisiae and Zygosaccharomyces bailii based on SYBR Green I staining of dsDNA that provides high resolution DNA measurements by single-cell analysis of large samples (Fortuna et al., 2000). As described below, an array of experiments was carried out to optimize staining conditions, using decreases in the half-peak coefficient of variation (HPCV), a statistical factor that inversely correlates with a homogenous and selective staining of dsDNA, as an indicator of protocol improvements for high-resolution DNA measurements (Fortuna et al., 2000).

\subsection{Protocol development for cell cycle analysis by FCM of $P$. brasiliensis yeast cells}

To characterize the cellular population of $P$. brasiliensis batch cultures by FCM, a light scatter analysis of forward scatter (FS LOG) and side scatter (SS LOG) was performed, parameters that are correlated to cell size and cell complexity, respectively. Yeast cell samples were collected at early stages of the exponential and stationary phases of growth. In line with observations from bright-field microscopy (Fig. 1, I), the biparametric analysis of P. brasiliensis stationary phase yeast cells correlating relative size and
I

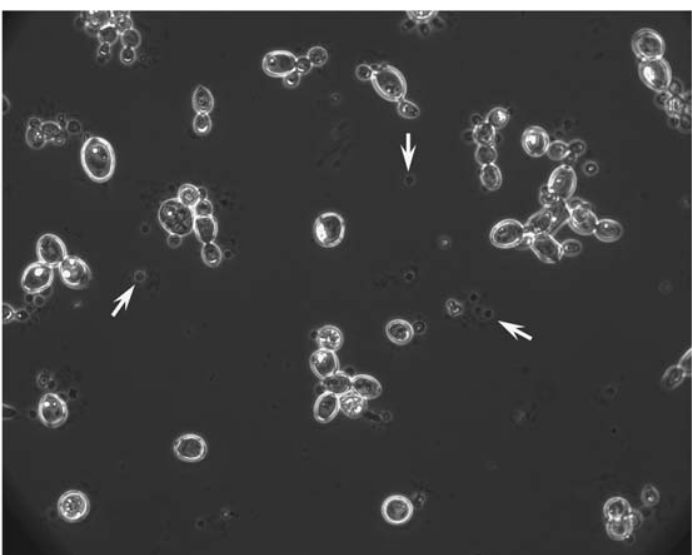

II

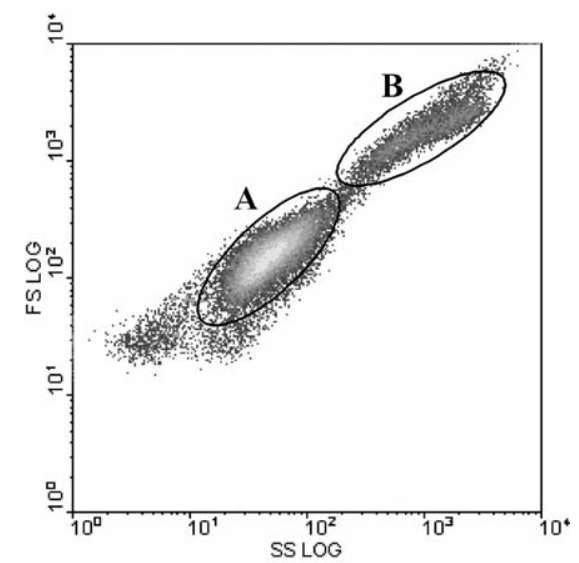

Fig. 1. P. brasiliensis stationary phase yeast cells in MMcM liquid medium. (I) Light microscopy analysis (dark field) of distinct cellular morphologies identified during batch culture (white arrows indicate small daughter cells). (II) Dot plot of logarithmic forward scatter (FS LOG) vs. logarithmic side scatter (SS LOG) of a light scatter analysis of unstained P. brasiliensis yeast cells; (A) and (B) represent subpopulations with low and high relative size and complexity, respectively. 
complexity revealed a vast heterogeneity in both parameters. The physical scattergram (Fig. 1, II) disclosed two major subpopulations: a subpopulation (A) most likely consisting of smaller and less complex cells with a more homogeneous morphology, and a subpopulation (B) with higher scatter values probably representing multiple budding cells or cell aggregates. Similar results were obtained with exponential growing cells (data not shown).

The flow cytometric analysis of ethanol-fixed P. brasiliensis yeast cells revealed a low specificity for SYBR Green I staining, with the appearance of poorly discriminated cell subpopulations with heterogeneous mean fluorescence intensities (Fig. 2, I-A). Under these conditions, the cytometric pattern did not present the characteristics of a cell cycle profile, in accordance with the observation of cytoplasmic diffuse fluorescence by epifluorescence microscopy (Fig. 2, II-A). Therefore, a series of pre-treatments with RNase A and proteinase $\mathrm{K}$ were carried out as described under Section 2. The pre-treatment of cell suspensions with $0.75 \mathrm{mg} / \mathrm{ml} \mathrm{RNase}$ A for $60 \mathrm{~min}$ at $50^{\circ} \mathrm{C}$ led to the discrimination of two major homogeneous subpopulations of cells with different DNA content $\left(\mathrm{R}_{1}\right.$ and $\left.\mathrm{R}_{2}\right)$ and a subpopulation of cells presenting a high and varying mean fluorescence intensity $\left(\mathrm{R}_{3}\right)$ (Fig. 2, I-B). Along with diminished HPCV values (Table 1), epifluorescence microscopy revealed that RNase A pre-treatment led to a more selective SYBR Green I staining of dsDNA, although some non-specific cytoplasmic distribution was still visible (Fig. 2, II-B). An increase in peak resolution was observed when cells were firstly treated with RNase A as above and subsequently with proteinase $\mathrm{K}\left(1 \mathrm{mg} / \mathrm{ml} ; 60 \mathrm{~min}\right.$ at $\left.50^{\circ} \mathrm{C}\right)$ (Fig. 2, I-C; Table 1), but not with a single proteinase $\mathrm{K}$ pre-treatment (data not shown). In addition, two new subpopulations were identified, $\mathrm{R}_{4}$ and $\mathrm{R}_{5}$, even though they represented very low percentages of the total population of cells and were not always discriminated (Fig. 2, I-C). As shown by Fig. 2 II-C, epifluorescence microscopy further corroborated selective nuclear SYBR Green I staining. The evaluation of individual subpopulations also revealed that $\mathrm{R}_{2}, \mathrm{R}_{4}$ and $\mathrm{R}_{5}$ each present, 2-, 3-, and 4-fold increases in the mean fluorescence intensity of $R_{1}$ (Table 1 ).

To assess the specificity of DNA labeling after RNase A and proteinase $\mathrm{K}$ pre-treatments, $P$. brasiliensis yeast cells were treated overnight with DNase before and after staining. The complete loss of green fluorescence in both conditions confirmed the DNA specific labeling (data not shown). In order to achieve a saturating mean fluorescence intensity associated with a minimum non-specific labeling, $P$. brasiliensis yeast cells, treated with RNase A and proteinase K, were stained with SYBR Green I at concentrations ranging from $0.01 \times$ to $100 \times$ (data not shown). Considering the array of tested SYBR Green I concentrations, $25 \times$ per $1 \times 10^{7}$ cells $/ \mathrm{ml}$ was chosen as an optimal dye-to-cell concentration ratio.

\subsection{Characterization of cell morphology and nuclei content of P. brasiliensis yeast cells}

With the aim of characterizing the cellular morphology and nuclei content of the various subpopulations discriminated during cell cycle profile analysis of $P$. brasiliensis yeast cells, samples were collected during the exponential phase of growth in BHI batch culture and submitted to cell cycle analysis. We then proceeded with physical separation by cell

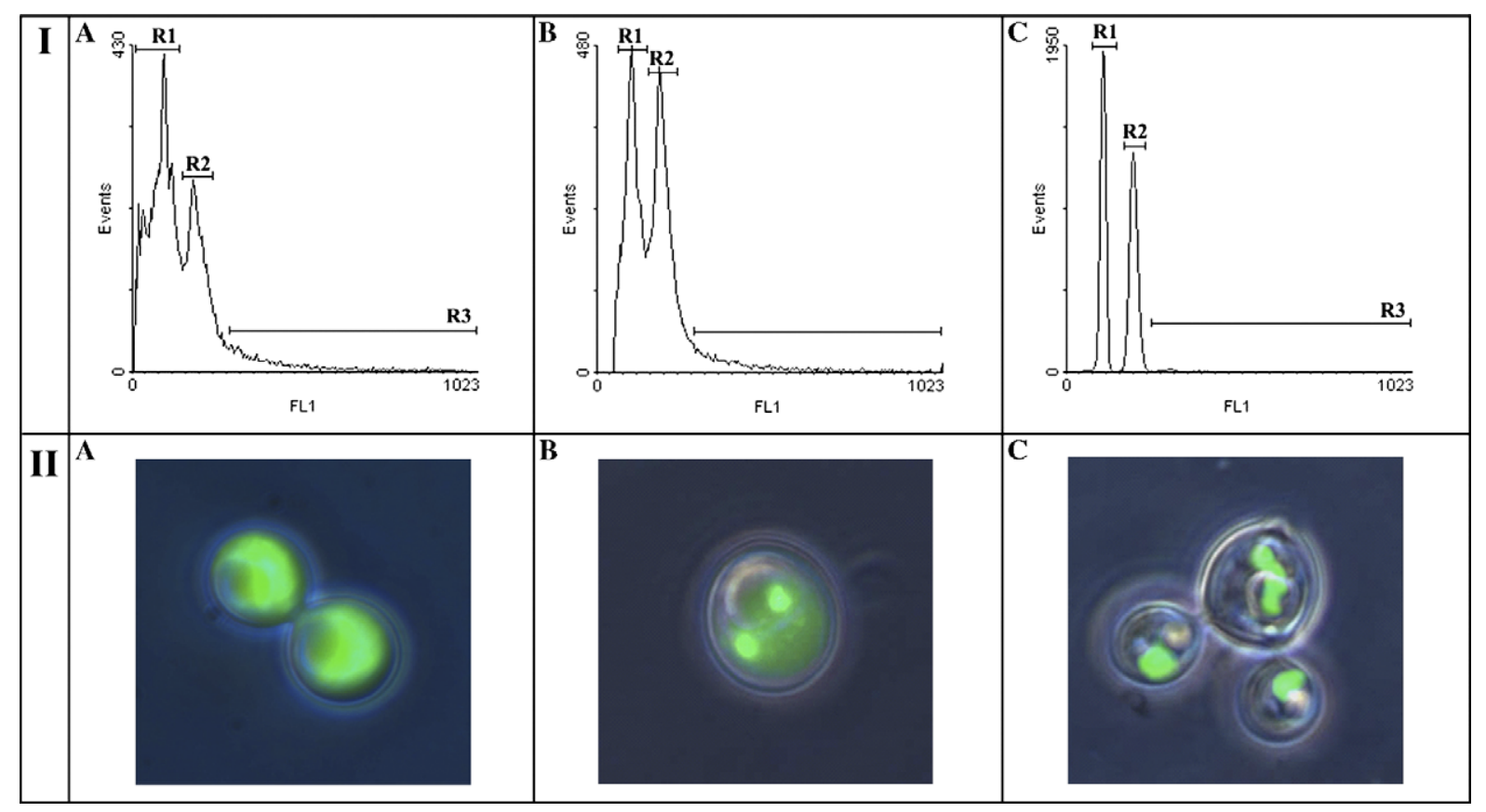

Fig. 2. P. brasiliensis yeast cells grown in MMcM batch cultures to the stationary phase, subjected to SYBR Green I staining. (A) Without pre-treatment; (B) treated with $0.75 \mathrm{mg} / \mathrm{ml}$ of RNase A for $60 \mathrm{~min}$ at $50^{\circ} \mathrm{C}$; (C) treated sequentially with RNase A as in (B) and $1 \mathrm{mg} / \mathrm{ml} \mathrm{of} \mathrm{proteinase} \mathrm{K} \mathrm{for} 60 \mathrm{~min}$ at $50^{\circ} \mathrm{C}$. (I) Monoparametic histograms of green fluorescence (FL1); (II) epifluorescence microscopy analysis (overlap of bright field and green fluorescence). 
Table 1

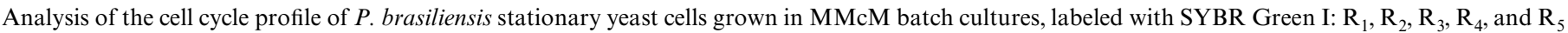

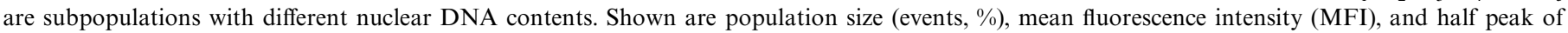
coefficient of variation ( $\mathrm{HPCV}, \%$ ) of each subpopulation

\begin{tabular}{|c|c|c|c|c|c|c|c|c|c|c|c|c|c|c|c|}
\hline & \multicolumn{3}{|l|}{$\mathrm{R}_{1}$} & \multicolumn{3}{|l|}{$\mathrm{R}_{2}$} & \multicolumn{3}{|l|}{$\mathrm{R}_{3}$} & \multicolumn{3}{|l|}{$\mathrm{R}_{4}$} & \multicolumn{3}{|l|}{$\mathrm{R}_{5}$} \\
\hline & Events & MFI & HPCV & Events & MFI & HPCV & Events & MFI & HPCV & Events & MFI & HPCV & Events & MFI & HPCV \\
\hline Non-treated & 48.9 & 95.0 & 25.0 & 38.6 & 193.2 & 22.3 & 10.4 & 592.8 & nd & nd & nd & nd & nd & nd & nd \\
\hline RNase $\mathrm{A}^{\mathrm{a}}$ & 44.5 & 101.8 & 10.7 & 43.1 & 198.1 & 11.5 & 9.8 & 575.5 & nd & nd & nd & nd & nd & nd & nd \\
\hline RNase $\mathrm{A}+$ proteinase $\mathrm{K}^{\mathrm{b}}$ & 47.1 & 100.4 & 4.5 & 43.5 & 201.0 & 5.2 & 8.4 & 553.1 & nd & 2.1 & 301.6 & nd & 0.7 & 402.3 & nd \\
\hline
\end{tabular}

nd, non-detected.

a Treatment with $0.75 \mathrm{mg} / \mathrm{ml} \mathrm{RNase} \mathrm{A}$ for $60 \mathrm{~min}$ at $50^{\circ} \mathrm{C}$.

b Sequential treatment with $0.75 \mathrm{mg} / \mathrm{ml} \mathrm{RNase} \mathrm{A} \mathrm{and} 1 \mathrm{mg} / \mathrm{ml}$ proteinase $\mathrm{K}$ for $60 \mathrm{~min}$ at $50{ }^{\circ} \mathrm{C}$.

sorting in accordance with specific parameters, namely relative size (FS LOG) and green fluorescence intensity (FL1 LOG), and selective gates were defined corresponding to $R_{1}$, $\mathrm{R}_{2}$ and $\mathrm{R}_{3}$ subpopulations (due to technical limitations subpopulations $R_{4}$ and $R_{5}$ were not individualized) (Fig. 3, I). FCM of sorted subpopulations revealed high purity separations: cells from $\mathrm{R}_{1}$ achieved $97.3 \%$, cells from $\mathrm{R}_{2} 80.5 \%$ and cells from $\mathrm{R}_{3} 87.4 \%$. Epifluorescence microscopy analysis of sorted cells showed that $\mathrm{R}_{1}$ subpopulation was composed by cells of reduced size containing only one nucleus (Fig. 3, IIA). On the other hand, $\mathrm{R}_{2}$ consisted of uninucleated and binucleated cells slightly larger than those in $\mathrm{R}_{1}$ (Fig. 3, IIB). Regarding $\mathrm{R}_{3}$, this subpopulation enclosed a heterogeneous group of cells concerning cell morphology and nuclei number (Fig. 3, II-C): both multiple budding cells with a variable number of nuclei as well as single cells with 3 or more nuclei were observed.

\subsection{Batch culture growth of $P$. brasiliensis yeast cells in defined and complex medium show differential patterns of cell cycle progression}

P. brasiliensis cells were cultured in batch system in defined (MMcM) and complex (BHI) media to assess specific differences of cell cycle profile during growth in poor and rich nutritional environment conditions. Samples were collected during growth and subjected to direct microscopic counts together with the FCM analysis of the nuclear DNA content of individual cells. The growth curve of $P$. brasiliensis in $\mathrm{MMcM}$ medium showed that the exponential phase occurred between 12 and $60 \mathrm{~h}\left(\mu=0.025 \pm 0.004 \mathrm{~h}^{-1}\right)$ while the stationary phase was initiated between 60 and $72 \mathrm{~h}$ (Fig. 4A). During the transition of the lag to the exponential phase the percentage of cells in subpopulation $R_{1}$ increased from 50.0 to $69.8 \%$ of the total population (Fig. 4B). Whereas the percentage of cells in subpopulation $\mathrm{R}_{1}$ remained approximately constant during the exponential phase, it continuously decreased up to $42.2 \%$ through the stationary phase. In contrast, the percentage of cells in subpopulation $\mathrm{R}_{2}(10 \%)$ remained unaltered until the late exponential phase, followed by an increase to $43.1 \%$ during the stationary phase. Between the end of the lag phase and the early exponential phase $(24 \mathrm{~h})$ the percentage of cells in subpopulation $\mathrm{R}_{3}$ diminished from 37.8 to $17.6 \%$. This proportion was maintained during the exponential phase and partially during the stationary phase up to $96 \mathrm{~h}$, decreasing to $11.4 \%$ at $120 \mathrm{~h}$. According to both cytometric physical parameters and epiffuorescence microscopy observations, a batch culture of $P$. brasiliensis yeast cells in the stationary phase of growth in $\mathrm{MMcM}$ medium, is characterized by the predominance of subpopulations $\mathrm{R}_{1}$ and $\mathrm{R}_{2}$, mostly represented by smaller uninucleated cells with a lower DNA content (Fig. 4C).

Regarding $P$. brasiliensis yeast cells cultured in batch system in BHI medium, the growth rate was only slightly higher than in MMcM medium $\left(\mu=0.040 \pm 0.008 \mathrm{~h}^{-1}\right)$. However, $P$. brasiliensis grown in BHI medium displayed a prolonged exponential phase (between 24 and $84 \mathrm{~h}$ ) followed by a transition to the stationary phase occurring between 96 and $108 \mathrm{~h}$ (Fig. 5A). During the transition from the lag to exponential phase of growth (until $24 \mathrm{~h}$ ) an increase in subpopulation $\mathrm{R}_{3}$ to $29.8 \%$ was observed (Fig. 5B). Throughout the exponential phase of growth, the percentage of cells in subpopulation $\mathrm{R}_{1}$ increased from 32.8 to $71.2 \%$, whereas at a later stationary phase a decrease to $50.9 \%$ was detected. On the other hand, subpopulation $\mathrm{R}_{2}$ was characterized by a decrease- 16.1 to $8.5 \%$-from the beginning of the exponential phase ( $24 \mathrm{~h})$ to the early stationary phase $(120 \mathrm{~h})$ followed by an augment to $13.4 \%$ at 180 h. Subpopulation $\mathrm{R}_{3}$ diminished from 29.8 to $6.5 \%$ until the early stationary phase, then increasing to $27.5 \%$ at $180 \mathrm{~h}$. Additionally, microscopy analysis showed that cells growing in BHI batch cultures presented distinct features such as pseudohyphae-like structures rather than the "typical" multiple budding cells present in cultures grown in MMcM medium (Fig. 5C).

\subsection{The fungicide benomyl triggers an arrest in the cell cycle progression of $P$. brasiliensis yeast cells}

With the intention of disturbing cell cycle progression of $P$. brasiliensis, we selected the fungicide benomyl since in other fungi it induces mitotic chromosome loss (Rodrigues et al., 2003) and cell cycle arrest in the $\mathrm{G}_{2} / \mathrm{M}$ phases (Jacobs et al., 1988; Wood, 1982a,b). Yeast cells were grown with a range of benomyl concentrations (from 5 to $250 \mu \mathrm{g} / \mathrm{ml}$ ) and samples were collected at intervals for cell cycle profile analysis. Cell viability assays determined by colony forming ability indicated that a final concentration up to $100 \mu \mathrm{g} / \mathrm{ml}$ 

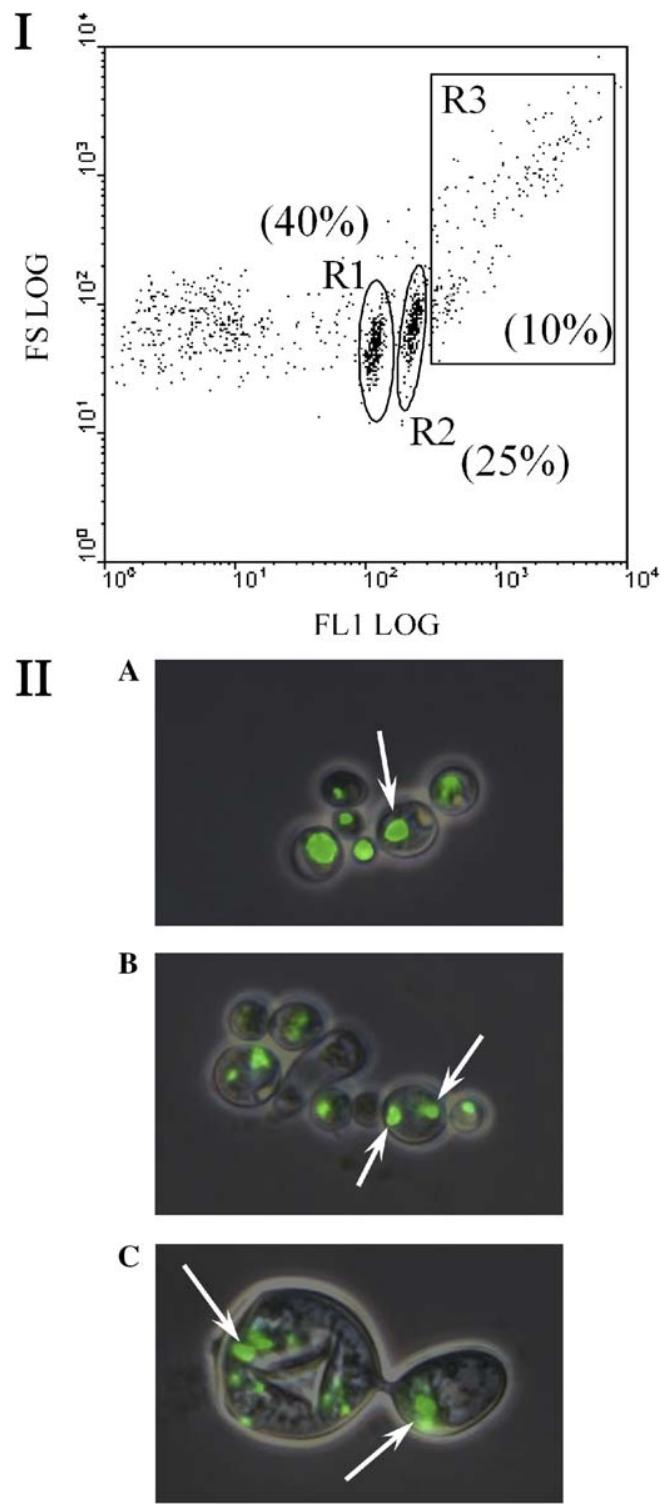

Fig. 3. P. brasiliensis yeast cells in the exponential phase of growth in BHI medium subjected to cell cycle analysis. (I) Representative dot plot of forward scatter (FS LOG) vs. green fluorescence intensity (FL1 LOG) with selective gates defined around subpopulations $\mathrm{R}_{1}, \mathrm{R}_{2}$, and $\mathrm{R}_{3}$ prior to cell sorting (cell percentage is represented in brackets). (II) Epifluorescence microscopy analysis of $P$. brasiliensis yeast cells after cell sorting (overlap of bright field and green fluorescence): cells sorted from subpopulation $\mathrm{R}_{1}$ (A), $R_{2}(B)$, and $R_{3}$ (C) (white arrows indicate SYBR Green I nuclear staining).

of benomyl did not result in survival changes (data not shown). In comparison with untreated controls, no differences were observed $(P>0.05)$ during the first $16 \mathrm{~h}$ of treatment in the cell cycle profile of $P$. brasiliensis yeast cells exposed to $100 \mu \mathrm{g} / \mathrm{ml}$ benomyl (Fig. 6). However, after $24 \mathrm{~h}$ benomyl-treated cells showed an increase in the percentage of cells in subpopulation $R_{3}$ and a decrease in subpopulations $\mathrm{R}_{1}$ and $\mathrm{R}_{2}$ (Fig. 6B). Throughout the remaining period of treatment (24-88 h), significant differences were detected between all subpopulations of treated and untreated cells $(P<0.005)$. At $88 \mathrm{~h}$, the percentage of benomyl-treated cells in subpopulations $\mathrm{R}_{1}, \mathrm{R}_{2}$, and $\mathrm{R}_{3}$ was 23.4 ,
$\mathbf{A}$

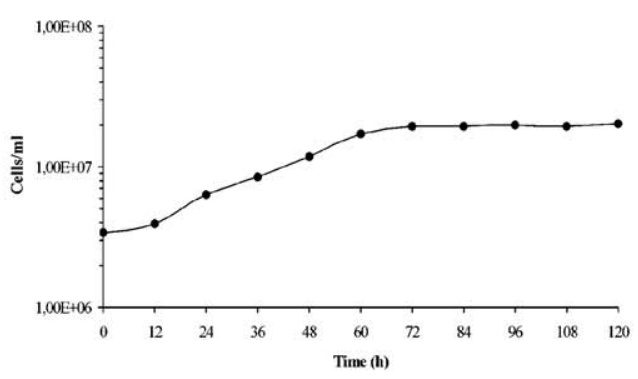

B

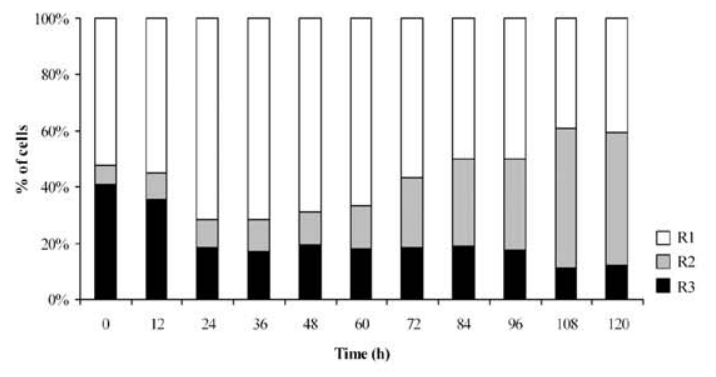

C
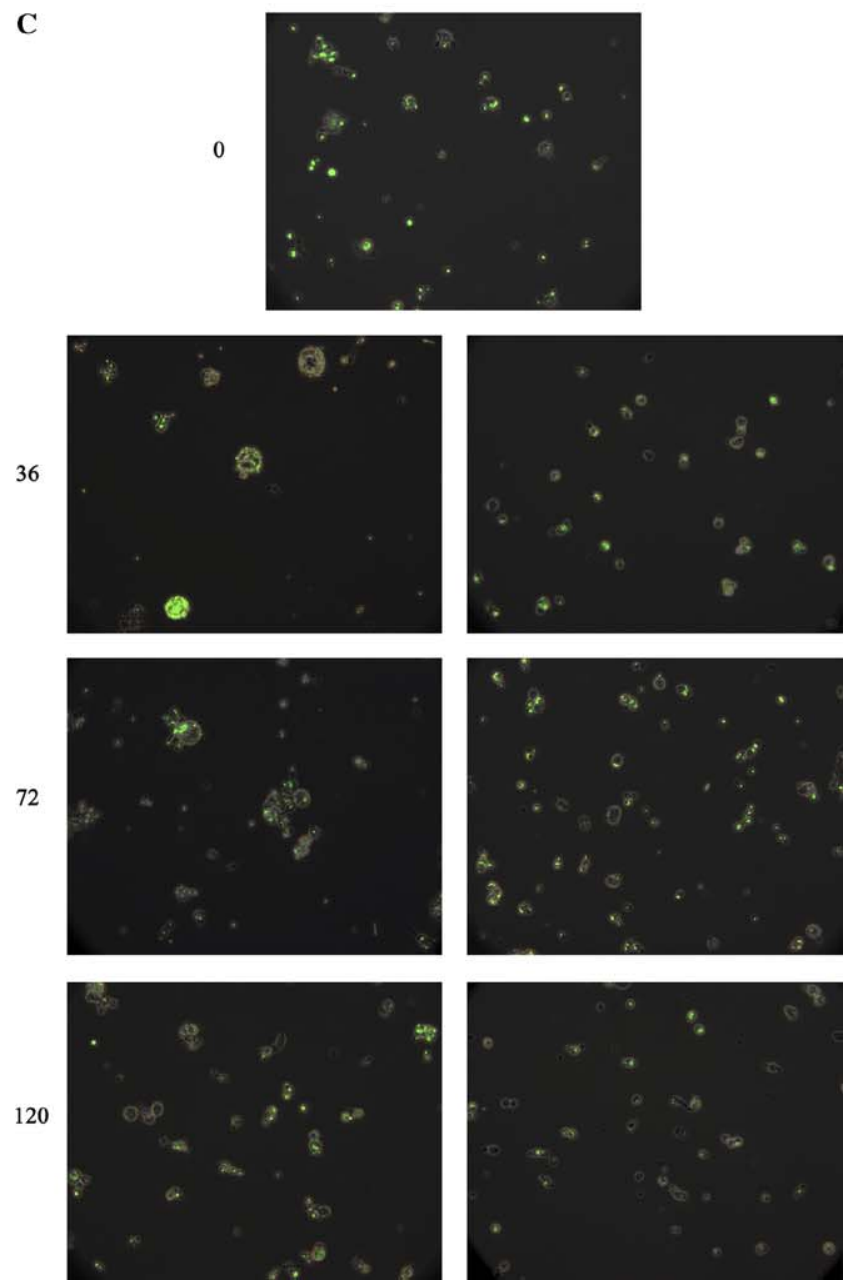

Fig. 4. Batch growing culture of $P$. brasiliensis yeast cells in $\mathrm{MMcM}$ medium. (A) Representative plot of a growth curve obtained by direct microscopic counts along time. (B) Cell cycle profile presented as the percentage of cells in each subpopulation $\left(\mathrm{R}_{1}, \mathrm{R}_{2}\right.$, and $\left.\mathrm{R}_{3}\right)$. (C) Epifluorescence microscopy analysis of different cellular morphologies detected at distinct phases of batch culture growth $(0,36,72$, and $120 \mathrm{~h})$. 
A

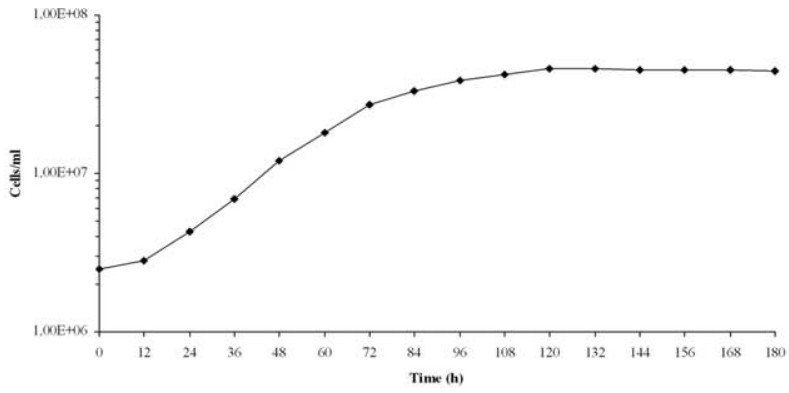

B

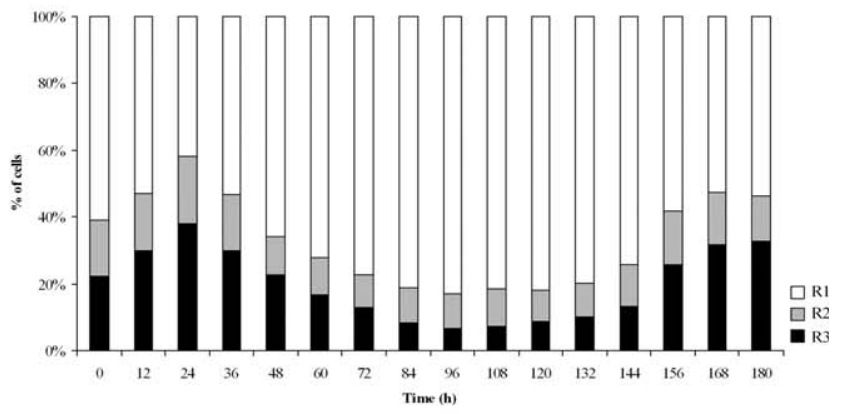

C
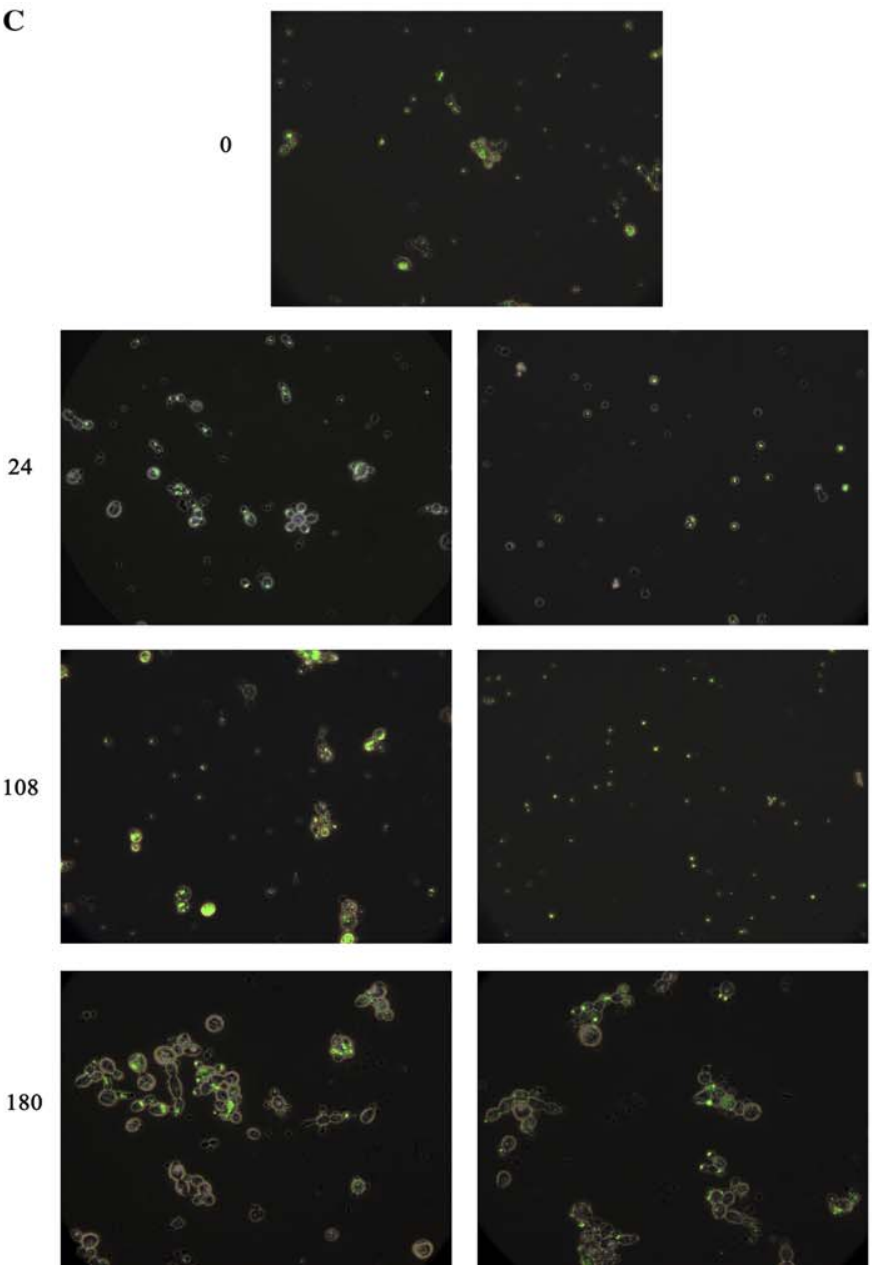

Fig. 5. Batch growing culture of P. brasiliensis yeast cells in BHI medium. (A) Representative plot of a growth curve obtained by direct microscopic counts along time. (B) Cell cycle profile presented as the percentage of cells in each subpopulation $\left(\mathrm{R}_{1}, \mathrm{R}_{2}\right.$, and $\left.\mathrm{R}_{3}\right)$. (C) Epifluorescence microscopy analysis of different cellular morphologies detected at distinct phases of batch culture growth $(0,24,108$, and $180 \mathrm{~h})$.
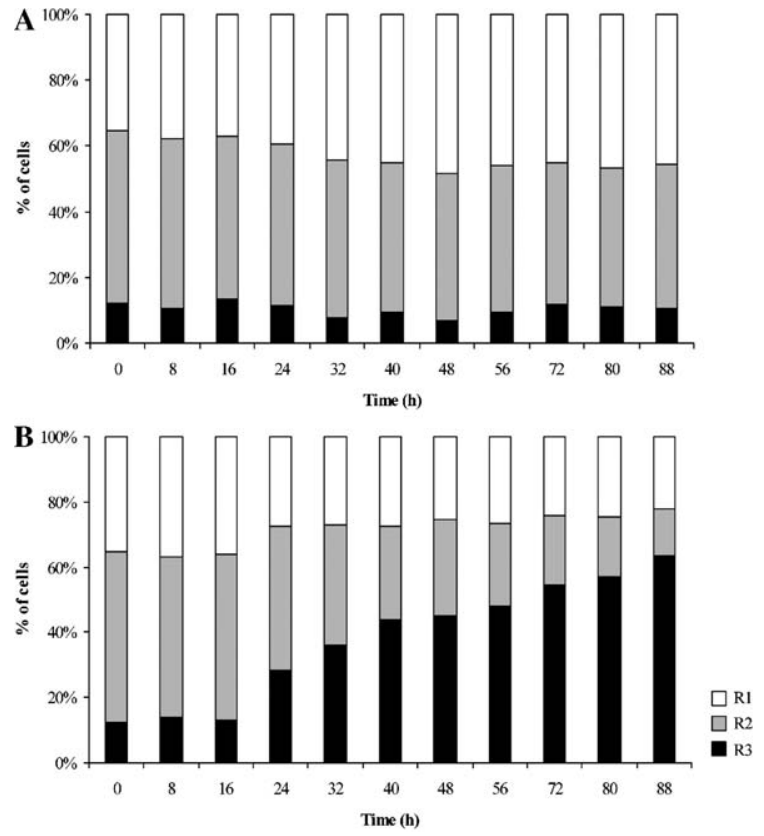

Fig. 6. Cell cycle profile of $P$. brasiliensis yeast cells growing in $\mathrm{MMcM}$ medium, presented as the percentage of cells in each subpopulation $\left(R_{1}\right.$, $\mathrm{R}_{2}$, and $\mathrm{R}_{3}$ ) in (A) absence (control with $1 \% \mathrm{DMSO}$ ) and (B) presence of $100 \mu \mathrm{g} / \mathrm{ml}$ of benomyl.

14.1 , and $60.6 \%$, respectively, whereas the untreated control presented $44.5,42.9$, and $12.2 \%$ of the same subpopulations (Fig. 6). We also found a dose-dependent effect of the fungicide regarding the arrest of cell cycle progression of $P$. brasiliensis yeast cells (data not shown).

\section{Discussion}

The main objective of this study was to evaluate the cell cycle profile of the pathogenic yeast form of the dimorphic fungus Paracoccidioides brasiliensis. In order to achieve this goal we optimized a flow cytometry technique for the analysis of nuclear DNA content, thus allowing the evaluation of cell cycle progression of $P$. brasiliensis yeast cells growing under different environmental conditions.

A major constraint regarding the application of flow cytometry for the analysis of $P$. brasiliensis yeast cells is the cell population heterogeneity which not only presents distinct multiple budding yeast cells but also cells with odd morphologies; additionally, accumulation of debris in its culture media hampers the potential approach of flow cytometric studies (Queiroz-Telles, 1994; RestrepoMoreno, 2003). Nonetheless, our results show that the cytofluorimetric analysis of this pathogenic fungus is practicable, indicating that the settings for an optimal cell cycle profile analysis of $P$. brasiliensis yeast cells based on nuclear DNA content are: (i) overnight cell fixation with $70 \%$ ethanol (vol $/ \mathrm{vol}$ ) at $4{ }^{\circ} \mathrm{C}$; (ii) ultrasonication of $1 \times 10^{7}$ cells $/ \mathrm{ml}$ (sodium citrate buffer; $50 \mathrm{mM}$; pH 7.5) with 3 ultrasound pulses at $40 \mathrm{~W}$ for $1 \mathrm{~s}$, with an interval of $1-2 \mathrm{~s}$ between each pulse; (iii) a subsequent pre-treatment, at 
$50^{\circ} \mathrm{C}$, with RNase A $(0.75 \mathrm{mg} / \mathrm{ml})$ and proteinase $\mathrm{K}(1 \mathrm{mg} /$ $\mathrm{ml}$ ) for $60 \mathrm{~min}$ each; (iv) overnight staining at $4{ }^{\circ} \mathrm{C}$ with SYBR Green I (25x), and (v) addition of Triton $(0.25 \%$; $\mathrm{vol} / \mathrm{vol}$ ) before acquisition by flow cytometry. Our results demonstrate that treatment with RNase A and proteinase $\mathrm{K}$ are essential for probe targeting of dsDNA with SYBR Green I. As other fungi, $P$. brasiliensis seems to have high levels of RNA thus hampering selective dsDNA staining (Futcher, 1993; Winson and Davey, 2000). Moreover, besides eliminating cell debris, proteinase $\mathrm{K}$ facilitates the access of fluorochrome to dsDNA and reduces nonspecific binding due to its important proteolytic activity against histones (Dien et al., 1994). Bearing in mind that P. brasiliensis yeast cell populations are extremely heterogeneous, half-peak coefficient of variation (HPCV) values ranging between 4.5 and $5.1 \%$ indicate an accurate and reliable dsDNA staining. Furthermore, the direct application of this method to P. brasiliensis yeast cells grown in a batch system discriminated subpopulations with both homogenous and heterogeneous mean fluorescence intensity. In fact, up to four different cellular subpopulations with homogeneous mean fluorescence intensity were distinguished $\left(\mathrm{R}_{1}, \mathrm{R}_{2}, \mathrm{R}_{4}\right.$, and $\left.\mathrm{R}_{5}\right)$ indicating one to four fold of genomic DNA content, characteristic of multiple budding and/or polynucleated cells. In view of these results, a query prior to cell cycle profile analysis under distinct growth conditions was to describe cell morphology and nuclei content of each individual subpopulation. In accordance with epifluorescence microscopy analysis (Fig. 3, II), cells within $\mathrm{R}_{1}$ most likely represent small uninucleated daughter cells. Regarding $R_{2}$, this subpopulation encloses both uninucleated and binucleated cells that may correspond to cells in different phases of the cell cycle. In addition, it is also possible that some of the cells in $R_{2}$ presenting two nuclei correspond not to dividing cells but to cells of multinucleate nature. On the other hand, cells with higher mean fluorescence intensity that belong to subpopulation $R_{3}$ correspond to cells with an elevated number of nuclei per individual cell, multiple budding cells and/or aggregates. These findings are consistent with the extensively described multinucleate and multiple budding nature of $P$. brasiliensis yeast cells (Restrepo-Moreno, 2003).

During batch growth cultures in defined (Fig. 4) or complex (Fig. 5) nutritional environments, a differential cell cycle progression of $P$. brasiliensis yeast form was observed. Contrary to what would be expected, a low percentage of cells with higher mean fluorescence intensity (subpopulation $\mathrm{R}_{3}$ ), characteristic of dividing cells, was observed during the exponential growth-phase in both media, although to a lesser extent in BHI. At the same time, an increase of cells in subpopulation $R_{1}$ was detected. An explanation for this behaviour might be that, contrary to "single" budding yeasts in which one mother cell gives rise to two daughter cells, a $P$. brasiliensis yeast mother cell may give rise to numerous progeny due to its typical multiple budding (Queiroz-Telles, 1994; RestrepoMoreno, 2003). It is likely that these variations in the cell cycle profile of exponentially growing cells result from a large increase in small daughter cells accompanying a higher growth rate. However, during the stationary phase of growth distinct cell cycle profiles were detected in both environments. In complex medium, we observed an increase in the percentage of cells in subpopulation $\mathrm{R}_{3}$ associated with the occurrence of pseudohyphae-like structures and cells with higher DNA content at later stages of this growth phase (Fig. 5). These results may suggest that de-regulation of the normal processes that coordinate DNA replication, nuclei segregation and cell division occurs under rich nutrition-environmental conditions. On the other hand, in defined medium a decline in $\mathrm{R}_{1}$ and $\mathrm{R}_{3}$ subpopulations was detected in parallel with an increase in subpopulation $\mathrm{R}_{2}$ in a stationary growthphase. Consequently, approximately $90 \%$ of the total population consisted of two major subpopulations having $1 n$ and $2 n$ DNA content ( $\mathrm{R}_{1}$ and $\mathrm{R}_{2}$, respectively), although the majority of the cells presented 1 nucleus and a much more homogenous morphology (Fig. 4). The stationary phase of growth of a microbial population is generally characterized by an arrest of the great majority of cells in $\mathrm{G}_{0} / \mathrm{G}_{1}$ phases of the cell cycle with a lower and unique DNA content (Herman, 2002). However, several reports indicate the existence of microorganisms that do not follow these same rules that usually coordinate cellular and nuclear division during cell growth. As demonstrated for $P$. brasiliensis yeast cells during this work, Archaeobacteria from the genus Sulfolobus and the pathogenic fungus Cryptococcus neoformans have also been shown to present two fully replicated genomes in a stationary-phase culture, demonstrating some level of independence between DNA duplication and cell division (Bernander, 1998; Hjort and Bernander, 2001; Takeo et al., 2004). Incidentally, commitment to budding in C. neoformans cells revealed not to be directly related to DNA synthesis or critical cell size requirement as in the yeast model system Saccharomyces cerevisiae, since large unbudded $\mathrm{G}_{2}$ cells are produced during the transition to the stationary phase of growth (Hartwell, 1974; Ohkusu et al., 2001). Additionally, the fungal pathogen Candida albicans was shown to regulate cell cycle in order to modulate cell shape while nuclear division was maintained also indicating alternative control mechanisms (Sudbery et al., 2004).

To further contribute to the elucidation of the differential patterns of cell cycle progression of $P$. brasiliensis yeast cells, this work also focused on the action of an antifungal drug during batch culture growth. Our results show that treatment with benomyl induces an arrest in the cell cycle profile (Fig. 6) and accumulation of cells in $\mathrm{R}_{3}$ subpopulation. These results suggest that even though benomyl progressively blocks nuclear division of $P$. brasiliensis yeast form, treated cells retain their DNA replication capacity, concurring with the effect it induces in other fungi (Rodrigues et al., 2003; Wood, 1982a,b). However, $P$. brasiliensis yeast cells accumulate in stages characterized by higher DNA content, rather than the $\mathrm{G}_{2} / \mathrm{M}$ phases 
of the cell cycle, consistent with its particular multinuclear and cellular division.

The methodology herein developed has allowed us to evaluate the cell cycle profile of $P$. brasiliensis yeast form growing under different environmental conditions. Even though this flow cytometry technique does not ascertain specific cell cycle phases, taken together our findings seem to show that this fungus may possess alternative control mechanisms during cell growth in order to manage its characteristic multiple budding and multinucleate nature. Nevertheless, future studies are required for the clarification of the biological phenomena that regulate nuclear/cellular division of $P$. brasiliensis.

\section{Acknowledgments}

We thank Professor Manuel T. Silva for stimulating discussions and for critical reading of the manuscript. We are indebted to Nuno Osório for technical assistance. Agostinho Almeida was financially supported by a fellowship from Fundação para a Ciência e Tecnologia, Portugal (Contract SFRH/BD/8655/2002). This work was supported by a research grant from Fundação para a Ciência e Tecnologia, Lisbon, Portugal (Grant No. POCTI/ESP/45327/ 2002).

\section{References}

Bernander, R., 1998. Archaea and the cell cycle. Mol. Microbiol. 29, 955-961. Dien, B.S., Peterson, M.S., Srienc, F., 1994. Cell-cycle analysis of Saccharomyces cerevisiae. Methods Cell Biol. 42 (Pt B), 457-475.

Fortuna, M., Sousa, M.J., Corte-Real, M., Leao, C., Salvador, A., Sansonetty, F., 2000. Cell cycle analysis of yeast. In: Current Protocols in Flow Cytometry. Wiley, New York, pp. 11.13.1-11.13.9.

Futcher, B., 1993. Analysis of cell cycle in Saccharomyces cerevisiae. In: Fantes, P., Broks, R. (Eds.), The Cell Cycle-A Practical Appoach. Oxford Press, Oxford, pp. 69-92.

Hartwell, L.H., 1974. Saccharomyces cerevisiae cell cycle. Bacteriol. Rev. 38, 164-198.
Hartwell, L.H., Culotti, J., Pringle, J.R., Reid, B.J., 1974. Genetic control of the cell division cycle in yeast. Science 183, 46-51.

Herman, P.K., 2002. Stationary phase in yeast. Curr. Opin. Microbiol. 5, 602-607.

Hjort, K., Bernander, R., 2001. Cell cycle regulation in the hyperthermophilic crenarchaeon Sulfolobus cidocaldarius. Mol. Microbiol. 40, 225-234.

Jacobs, C.W., Adams, A.E., Szaniszlo, P.J., Pringle, J.R., 1988. Functions of microtubules in the Saccharomyces cerevisiae cell cycle. J. Cell Biol. 107, 1409-1426.

Ohkusu, M., Hata, K., Takeo, K., 2001. Bud emergence is gradually delayed from $\mathrm{S}$ to $\mathrm{G} 2$ with progression of growth phase in Cryptococcus neoformans. FEMS Microbiol. Lett. 194, 251-255.

Queiroz-Telles, F., 1994. Paracoccidioides brasiliensis ultrastructural findings. In: Franco, M., Lacaz, C.S., Restrepo-Moreno, A., Del Negro, G. (Eds.), Paracoccidioidomycosis. CRC Press, London, pp. $27-44$.

Restrepo, A., Jimenez, B.E., 1980. Growth of Paracoccidioides brasiliensis yeast phase in a chemically defined culture medium. J. Clin. Microbiol. 12, 279-281.

Restrepo-Moreno, A., 2003. Paracoccidioidomycosis. In: Dismukes, W.E., Pappas, P.G., Sobel, J. (Eds.), Clinical Mycology. Oxford University Press, New York, pp. 328-345.

Rodrigues, F., Ludovico, P., Sousa, M.J., Steensma, H.Y., Corte-Real, M., Leao, C., 2003. The spoilage yeast Zygosaccharomyces bailii forms mitotic spores: a screening method for haploidization. Appl. Environ. Microbiol. 69, 649-653.

San Blas, F., 1986. Ultrastructure of spore formation in Paracoccidioides brasiliensis. J. Med. Vet. Mycol. 24, 203-210.

San Blas, G., Nino-Vega, G., Iturriaga, T., 2002. Paracoccidioides brasiliensis and paracoccidioidomycosis: molecular approaches to morphogenesis, diagnosis, epidemiology, taxonomy and genetics. Med. Mycol. 40, 225-242.

Sudbery, P., Gow, N., Berman, J., 2004. The distinct morphogenic states of Candida albicans. Trends Microbiol. 12, 317-324.

Takeo, K., Ogura, Y., Virtudazo, E., Raclavsky, V., Kawamoto, S., 2004. Isolation of a CDC28 homologue from Cryptococcus neoformans that is able to complement cdc28 temperature-sensitive mutants of Saccharomyces cerevisiae. FEMS Yeast Res. 4, 737-744.

Winson, M.K., Davey, H.M., 2000. Flow cytometric analysis of microorganisms. Methods 21, 231-240.

Wood, J.S., 1982a. Genetic effects of methyl benzimidazole-2-yl-carbamate on Saccharomyces cerevisiae. Mol. Cell. Biol. 2, 1064-1079.

Wood, J.S., 1982b. Mitotic chromosome loss induced by methyl benzimidazole-2-yl-carbamate as a rapid mapping method in Saccharomyces cerevisiae. Mol. Cell. Biol. 2, 1080-1087. 